\title{
Asylum application process: the psychiatric patient's experience
}

\author{
Alexandra Pitman ${ }^{1}$ \\ ${ }^{1}$ Department of Mental Health \\ Sciences, University College London \\ Medical School \\ Correspondence to \\ Alexandra Pitman \\ (a.pitman@medsch.ucl.ac.uk)
}

The Psychiatrist (2010), 34, 344-348, doi: 10.1192/pb.bp.109.024968

Summary Clinicians in all specialties may encounter patients who are in the process of seeking asylum in the UK. This article outlines the practical realities of this process, particularly the legal, social, and economic challenges faced by applicants, and the long wait for resolution. These are highlighted as factors that may have an impact on the psychological health and social functioning of patients. This social and economic context is of particular interest to mental health professionals involved in the care of asylum-seekers; assisting in the process of case formulation, risk assessment, care planning, and the preparation of medico-legal reports.

Declaration of interest This article was written while working as a higher trainee in general adult psychiatry in Haringey, an inner London borough with a relatively high proportion of individuals subject to immigration control and with no recourse to public funds.
Mental health professionals, and indeed clinicians in all specialties, may encounter patients who are involved in the process of an asylum application. The condition for which they are treated may be directly or indirectly linked to pre-migration trauma, and this may sometimes be cited as a reason for seeking asylum. These patients often report the frustration of the long wait for resolution of their case, with the threat of deportation as a chronic stressor. Although history-taking often acknowledges the roles that pre-migration and post-migration adversities play in the history of the presenting complaint, clinicians are not always clear about the practical realities involved in making an asylum application. A series of Home Office regulations govern arrangements for applying to study, work or reside in the UK, as well as entitlement to benefits, and the UK Border Agency is responsible for enforcing them. The legal and administrative procedures governing these pathways are complex, even for those with English as a first language. This article outlines the immigration legal process for adults, setting it in the context of other post-migration adversities, to help clinicians understand the legal and socioeconomic challenges faced by some of their patients. This information should serve as clinically useful in formulating appropriate treatment plans, designing risk management plans, and in preparing medico-legal reports where requested for asylum applications. It should be noted that asylum applications for unaccompanied minors are processed quite differently and are not discussed here.

\section{Defining the asylum-seeker population}

The 1951 United Nations Convention Relating to the Status of Refugees defines asylum as protection provided for those who are unable to go back to their country because of a wellfounded fear of persecution on grounds of race, religion, nationality, political opinion, or membership of a social group. Asylum-seekers are often defined as any individual who has applied for asylum on the basis of persecution within their country of origin, while refugees are those whose asylum application has been successful. ${ }^{1}$ However, under the Refugee Convention, a refugee becomes so at the point at which they leave their country of origin in fear of persecution, and thus accrues certain rights, even though it may be some time later that formal refugee status is conferred.

In the UK, applications for asylum are made to the UK Border Agency. Applicants who do not qualify for refugee status, humanitarian protection leave or discretionary leave, may attempt to apply for temporary permission to remain on humanitarian grounds. Those whose asylum applications are turned down, or whose temporary leave is not renewed, are expected to return home voluntarily or face deportation, a process termed removal by the Home Office. The UK Border Agency is also bound by the European Convention on Human Rights, which prevents a person from being deported to a country where there is a real risk that they will be exposed to torture, or inhuman or degrading treatment. These legal principles distinguish refugees and asylum-seekers from economic or traditional migrants, acknowledging the human rights violations responsible for these displacements. ${ }^{2}$

Of the 23430 people who applied for asylum in the UK in 2007, the majority were of Afghan, Iranian, Chinese, Iraqi and Eritrean origin. ${ }^{3}$ Those with low levels of proficiency in English, and inadequate numeracy and literacy would have 
experienced a greater struggle to find legal representation and subsistence during the long wait for resolution.

\section{Burden of mental illness in the asylum-seeker population}

The mental health of asylum-seekers has not been well investigated, partly because of methodological difficulties in data collection. Caution must be exercised in extrapolating from the evidence base on the mental health of refugees as psychosocial stressors differ in the two populations. Migrants held in detention centres are also a distinct population. $^{4-7}$ There are questions about the appropriateness of diagnostic categories such as post-traumatic stress disorder (PTSD) in migrant groups ${ }^{8}$ but the core symptoms may simply be articulated differently in Western society when compared with other cultures. ${ }^{2}$ People do cope with adversity in very different ways, and although the World Health Organization recognises a spectrum of psychiatric morbidity in this population, it also warns against assuming that all refugees and asylum-seekers are in need of psychiatric care. ${ }^{9}$

The existing epidemiological data do suggest high rates of PTSD and depression in refugees and asylum-seekers, but with widely varying prevalence rates. ${ }^{1,10-13}$ Australian data have shown an association between delays in processing refugee applications and likelihood of PTSD diagnosis. ${ }^{13}$ Other studies have described a high proportion of somatic presentations in asylum-seeker and refugee populations, ${ }^{14,15}$ but there is a concern that such medicalised concepts fail to capture the complexity of distress, demoralisation, and loss of autonomy experienced in this population. There is very poor recording of rates of self-harm and suicide in this group but existing data suggest the risk to be high among detainees. $^{7}$ Early feedback from local suicide audits indicates that an increasing proportion of cases were suicides by recent immigrants, ${ }^{16}$ yet it is not clear whether asylum-seekers are represented at a higher rate than expected, or indeed what proportion had diagnosable mental illness. Community-based asylum-seekers presenting with suicidal behaviour may represent the tip of a clinical iceberg given the problems this group experience in accessing primary care or psychiatric services, and in overcoming language barriers.

\section{Asylum application process}

Applying for asylum in the UK may be summarised in the following stages. As the system is subject to ongoing transitional changes, updates can be found on the UK Border Agency website.

\section{Application}

The asylum process commences with an application to the UK Border Agency, either at the port of entry or at their offices in Croydon (London). At this screening appointment an interpreter can be used if needed, an application registration card (ARC) is issued as a form of identity, and passports or travel documents are retained by the UK Border Agency until case resolution. The applicant may be able to make reference to their grounds for the threat of persecution but a claimant should not be asked to outline their claim at this stage. The aim is for each case to be concluded within 6 months, but this timeframe may be exceeded substantially when appeals are involved, where there are errors in recording information, or where further information is required.

\section{Initial meeting}

The arrangement is for a 'case owner' to be allocated formally at the first reporting event, with responsibility for seeing the case through. At the initial meeting with the case owner the asylum process is explained, including any instructions on regular reporting (e.g. weekly visits to a regional office), and advice is given on how to find legal representation and financial support. However, in many cases this meeting does not take place. An asylum interview is then arranged for approximately a week after this initial meeting; this is the opportunity for the applicant or their solicitor to provide full details of the asylum application. Non-attendance by the applicant is met by an automatic refusal. At this early stage in the application process the pace may be perceived as rapid. For those not familiar with British culture there may be a struggle to find a solicitor in time. Postponements of the asylum interview are rarely allowed and it will proceed whether one is found or not. Even if a solicitor is identified, legal aid will not necessarily cover their attendance, and if they cannot attend, taperecordings must be requested at least a day in advance.

\section{Decision}

The case owner considers the evidence gathered at interviews, any written evidence proving the threat to that person in their country of origin, and the UK Border Agency's current intelligence on levels of threat there. A decision is made on the basis of this information. An unsuccessful outcome is communicated by letter, with each Agency envelope provoking a surge of anxiety about the possibility of imminent removal. A successful outcome confers refugee status, or permission to stay for humanitarian reasons, and temporary leave is granted for that individual (and any of their dependants) to remain for an initial 5 years. In some cases discretionary leave to remain may be granted for up to 3 years. Those given asylum or humanitarian status can then officially commence the integration process. They are eligible to work or to receive benefits, can apply for an interest-free integration loan, and also for travel documents. Under the family reunion programme they can apply for a partner and children (and in some circumstances other relatives) to enter the UK and be reunited with them. Travel to the country of origin is obviously not permitted. At the end of the period of leave to remain an application can be made for its renewal, and those who have been in the UK for at least 6 years may apply for permanent residence.

\section{Refused applications}

If the case owner judges the initial asylum application to be unsuccessful, the applicant is asked to leave voluntarily, for 
which assistance is available, or faces deportation. Any cash support or accommodation ends within 21 days, unless the applicant has dependants under 18. The applicant or their solicitor has 10 working days (5 days if in detention) in which they can appeal to an appeals tribunal, an independent judicial body. Its immigration judges are appointed by the Lord Chancellor and are thus independent from the Home Office. A single immigration judge, or a panel including non-legal members, hears appeals at a number of hearing centres across the UK. Both the case management review hearing and a subsequent full hearing are attended by the applicant, their legal representative and a UK Border Agency representative. Non-attendance at either hearing by the applicant or their legal representative can result in automatic dismissal. Following the full hearing, the judge or panel issues the applicant and the UK Border Agency with a written 'determination' over whether the appeal should be allowed or dismissed, with the whole process taking a minimum of 6 weeks, and in some cases considerably longer. An appeal may be brought against the decision of an immigration judge only on error of law grounds, and such appeals are heard by a second tier of the appeals tribunal. In some cases it may be possible to appeal further to the Court of Appeal, but this would only be on the basis that a decision was legally flawed. If an appeal is ultimately unsuccessful, unless grounds of ill health or clear danger in the country of origin can be invoked, the applicant faces removal and may be held in a detention centre until return to the country of origin.

\section{Medico-legal reports}

Where grounds of mental or physical ill health are invoked the applicant provides their solicitor with details of a treating clinician to whom a request is made for a medicolegal report. ${ }^{17}$ Payment for these reports is made by the applicant unless supported by legal aid. The report usually requires the clinician to include full details of the medical history and clear responses to specific questions regarding risk. Specifically, they may be asked to state their opinion as to the clinical risks involved in returning an applicant to their country of origin, taking into account their current condition, the treatments available in that country, and the risks involved in travel. The clinician must be clear whether a return to the country of origin would worsen the condition, either due to inadequate treatment or to a specific threat to mental or physical health. This information is not always available. In producing such reports a difficult dynamic may be established between patient and clinician, granting the clinician the uncomfortable power to make an apparent life or death decision. Unfavourable decisions may be perceived by the patient as a betrayal, and the economic transaction is an uncomfortable one given clear inequalities in wealth.

\section{Renewal of application}

Some applicants are only granted temporary permission to stay in the UK as a refugee for humanitarian protection or for other reasons. The process by which this is reviewed depends on the type of permission given as well as the specific year in which it was granted, and given ongoing legislative changes the situation is confusing. When an application is made for renewal the case might be reviewed to see if any factors (e.g. a criminal record or any use of deception) might undermine their case for requiring protection, and if none was found indefinite leave to remain could be granted. If such factors did come into play, a process of 'active review' would be undertaken to support justification of ongoing residence. If an applicant's circumstances or the situation in their country of origin are judged to have changed, the application may also be turned down. Again, there exists a right of appeal but a failed appeal would result in voluntary or enforced removal. Those whose initial asylum application gained them temporary residence, but whose renewal request has failed, may have to sever established work and community ties to return to what they perceive as a hostile environment.

\section{Detention}

Detention centres (now termed immigration removal centres by the Home Office) can be utilised at any stage of the asylum process, and a government expansion programme has resulted in increasing proportions of people held under the Immigration Act 1971 powers. ${ }^{18}$ Detention may be used after an initial application to determine the applicant's identity and the basis of their claim, or in fast-track asylum procedures. It can be used where there is deemed to be any risk of absconding, and at the end of the process pending the removal of failed asylumseekers. Detention centres in the UK have been criticised for infringing on the human rights of asylum-seekers; ${ }^{19}$ widespread abuse has been documented. ${ }^{20,21}$

\section{Volume of work}

In 2007, a total of 14935 asylum appeals were heard by the Asylum and Immigration Tribunal, of which $23 \%$ were allowed and $72 \%$ were dismissed. ${ }^{4}$ Between 2005 and 2008 the Court of Appeal saw a $77 \%$ increase in appeal applications for asylum and immigration cases, together with a rise in reconsiderations of decisions by the UK Border Agency or Asylum and Immigration Tribunal. ${ }^{22}$ It is this rise in appeals, rather than new applications, which accounts for a substantial backlog of cases, exacerbated by the 2004 creation of a single-tier system bottlenecking cases through the High Court. Pressure groups such as the Public Law Project challenged this arrangement as breaching Article 6 of the European Convention on Human Rights which guarantees an effective court system. Such have been the delays in hearing cases that the timeframe for an asylum application involving appeals has been typically 1-2 years. Clinicians can encounter patients who have waited over 5 years. A 2008 ruling to bring more judges into the system was intended to increase the rate of asylum and immigration appeals heard from the existing 8000 per year and to reduce waiting times. ${ }^{22}$ In early 2010, following a period of consultation, a new unified tribunals framework was established to replace the Asylum and Immigration Tribunal, and the impact of this is yet to be evaluated. 


\section{Sources of financial support}

The personal resources required to lodge an asylum application and to support oneself and any dependants throughout the process can leave an applicant in a state of economic hardship. The UK Border Agency has funds available to those applicants who are unable to support themselves or their families, but eligibility is not guaranteed. Those who make their application some time after their arrival in the UK may meet these eligibility criteria. This presents a problem for people who travel to the UK and subsequently learn of the persecution of friends or family members back at home, raising their own risk on returning there. Unless they can be supported using resources accessed from the voluntary sector, they may have to rely on the goodwill of their own ethnic or religious communities.

An assessment is made of financial need at the start of the application process and the applicant is given details of local One Stop Services for further advice. The advice in these regional centres is provided by independent charitable organisations such as the Refugee Council, Refugee Action, the North of England Refugee Service, and Migrant Helpline. If the case owner judges that an asylum-seeker is eligible, short-term financial support is available in the form of money, food vouchers and accommodation, provided by the National Asylum Support Service, established under the Immigration and Asylum Act 1999 and provided within the Home Office. These amounts depend on age and number of dependants but are less than the equivalent income support payments for British residents. Any failure to fulfil reporting requirements may result in the cessation of financial support and possible detainment. Many applicants face geographical and financial barriers in meeting reporting requirements. Factors such as acute illness, a sick dependant, or transport disruptions such as strikes undermine an applicant's attendance record, threatening both their access to support and the success of their legal case.

Where accommodation is provided, no choice is offered over the geographical location. Provision in the south-east of England is very limited. It is common for applicants in London or the south-east who need longer-term accommodation to be dispersed to housing in other regions of the UK. This might arise, for example, if an individual's application process was extended or if their financial circumstances changed. The government's controversial dispersal policy is designed to even out responsibility for the provision of support but has a potentially disruptive effect on continuity of care, particularly for those being treated for mental health problems or in tertiary centres, and on any support networks already established. ${ }^{10}$ For patients with severe psychiatric disorder the UK Border Agency will accept a challenge from the responsible clinician and consider deferral of dispersal on grounds of safety to self and others and continuity of care. ${ }^{23}$ For other recipients a refusal to move may result in termination of support. A dispersal order may therefore constitute a post-migration adversity regardless of outcome.

Patients often perceive decisions over dispersal or non-eligibility for support as being made on the apparent whim of a nameless official, and can feel let down by the
Home Office, the UK Border Agency, the local authority, or their solicitor, engendering feelings of powerlessness and frustration. If an application is rejected, short-term support may be available while waiting to return to the country of origin under the terms of Section 4 of the Immigration and Asylum Act 1999. This Section 4 support is very restricted, involves vouchers or pre-payment cards and accommodation, and may require any involved medical professionals to account for specific medical reasons or other physical barrier preventing that person from leaving the UK.

\section{Other post-migration adversities}

A range of psychosocial stressors affect asylum-seekers awaiting the outcome of their application, including racist abuse, racially motivated crime, destitution, social stigma, and ineligibility to work. ${ }^{1}$ Racist abuse may be worse in economically deprived areas or during periods of economic decline and unemployment, and media coverage tends to feed negative perceptions. ${ }^{24}$ Asylum-seekers describe a stigma associated with the use of food vouchers and with housing stock set aside for the National Asylum Support Service. Ineligibility to work applies to all those who have waited less than a year for their application to be decided. Even then permission to work is restricted to certain types of work (e.g. self-employment is not allowed) and is only given if the applicant has not been judged responsible for any delay in the UK Border Agency reaching an initial decision on the application. Asylum-seekers have access to free National Health Service (NHS) healthcare unless their application fails. Following a 2009 Court of Appeal ruling, failed asylum-seekers are only entitled to emergency care or care at the discretion of the relevant NHS trust. In tension with concerns about increasing pressures on primary care, ${ }^{25}$ and on NHS budgets as a whole, ${ }^{26}$ are arguments about the ethics and public health impact of withholding healthcare from those in need. ${ }^{27,28}$

\section{Conclusion}

British legal systems appear to be struggling under the weight of asylum applications and appeals, with cases remaining unresolved for a number of years. This description of the immigration legal process illustrates the range of chronic and acute psychosocial stressors involved: the chronic threat of removal, the strain of non-resolution, and the acute anxiety precipitated by the arrival of each decision letter. These constitute a potential threat to psychological health, particularly for those with a history of pre-migration trauma. In understanding this process more fully mental health professionals are better able to contextualise their patients' problems, helping to predict and interpret fluctuations in risk, and formulate culturally appropriate management plans. Although improvements in the immigration courts are in process, health and social care and other government agencies may need to work together more closely in order to harmonise what society can provide with the needs of those seeking asylum. 


\section{About the author}

Alexandra Pitman is an MRC Research Fellow at the Department of Mental Health Sciences, University College London Medical School.

\section{References}

1 McColl H, McKenzie K, Bhui K. Mental healthcare of asylum-seekers and refugees. Adv Psychiatr Treat 2008; 14: 452-9.

2 Mollica RF, Culhane AM, Hovelson DH. The special psychiatric problems of refugees. In New Oxford Textbook of Psychiatry (2nd edn) (eds M Gelder, N Andreasen, J Lopez-lbor, J Geddes): 1493-500. Oxford University Press, 2009.

3 Home Office. Asylum statistics United Kingdom 2007. Home Office Statistical Bulletin 2008; 11: 1-94.

4 Steel Z, Silove D, Brooks R, Momartin S, Alzuhairi B, Susljik I. Impact of immigration detention and temporary protection on the mental health of refugees. Br J Psychiatry 2006; 188: 58-64.

5 Robjant K, Hassan R, Katona C. Mental health implications of detaining asylum seekers: systematic review. Br J Psychiatry 2009; 194: 306-12.

6 Keller AS, Rosenfeld B, Trinh-Shevrin C, Meserve C, Sachs E, Leviss JA, et al. Mental health of detained asylum seekers. Lancet 2003; 362 : 1721-3.

7 Cohen J. Safe in our hands? A study of suicide and self-harm in asylum seekers. J Forensic Leg Med 2009; 15: 235-44.

8 Summerfield D. The invention of post-traumatic stress disorder and the social usefulness of a psychiatric category. BMJ 2001; 322: 95-8.

9 Brundtland $\mathrm{GH}$. Mental health of refugees, internally displaced persons and other populations affected by conflict. Acta Psychiatr Scand 2000; 102: 159-61.

10 Murphy D, Ndegwa D, Kanani A, Rojas-Jaimes C, Webster A. Mental health of refugees in inner-London. Psychiatr Bull 2002; 26: 222-4.

11 Silove D, Sinnerbrink I, Field A, Manicavasagar V, Steel Z. Anxiety, depression and PTSD in asylum-seekers: associations with premigration trauma and post-migration stressors. Br J Psychiatry 1997; 170: $351-7$

12 Adams KH, Gardiner LD, Assefi N. Healthcare challenges from the developing world: post-immigration refugee medicine. BMJ 2004; 328 $1548-52$.

13 Fazel $M$, Wheeler J, Danesh J. Prevalence of serious mental disorder in 7000 refugees resettled in western countries: a systematic review. Lancet 2005; 365: 1309-14.
14 Lin EHB, Carter WB, Kleinman AM. An exploration of somatisation among Asian refugees and immigrants in primary care. Am J Public Health 1985; 75: 1080-4.

15 Summerfield D. Asylum-seekers, refugees and mental health services in the UK. Psychiatr Bull 2001; 25: 161-3.

16 National Institute for Mental Health in England. National Suicide Prevention Strategy for England: Annual Report on Progress 2007. Department of Health, 2008.

17 Pitman A. Medicolegal reports in asylum applications: a framework for addressing the practical and ethical challenges. J R Soc Med 2010; 103. 93-7.

18 Home Office. Control of Immigration: Quarterly Statistical Summary, United Kingdom - Second Quarter 2009. Home Office, 2009 (http:// rds.homeoffice.gov.uk/rds/pdfs09/immiq209.pdf/).

19 Pourgourides C. A second exile: the mental health implications of detention of asylum seekers in the UK. Psychiatr Bull 1997; 21: 673-4.

20 Cohen D. Asylum seekers in detention centres receive poor medical care, MP says. BMJ 2008; 337: a3022.

21 Arnold F, Ginn E, Wistrich H. Outsourcing Abuse: The Use and Misuse of State-Sanctioned Force During the Detention and Removal of Asylum Seekers. Birnberg Peirce \& Partners, Medical Justice and the National Coalition of Anti-Deportation Campaigns, 2008.

22 Gibb F. Extra judges drafted in to hear immigration appeals. The Times 2008; 15 December.

23 Ani C. Working with asylum seekers with mental illness distressed by the Home Office dispersal programme. Psychiatr Bull 2007; 31: 307-9.

24 Conay $M$, Beutin $R$, Horvath $A$, Hubert $A$, Lerais $F$, Smith $P$, et al. Migration and Public Perception. Bureau of European Policy Advisers (BEPA), European Commission, 2006.

25 Correa-Velez I, Johnston V, Kirk J, Ferdinand A. Community-based asylum seekers' use of primary health care services in Melbourne. Med J Australia 2008; 188: 344-8.

26 Newdick C. Treating failed asylum seekers in the NHS. BMJ 2009; 338 b1614.

27 Williams PD. Why failed asylum seekers must not be denied access to the NHS. BMJ 2004; 329: 298.

28 Yates R, Moore L, Birch M, Yudkin JS, Macara A. Bad news for everyone. BMJ 2009; 338: b1597. 